\title{
STRATEGIC APPROACH \\ TO PURCHASING PROCESS IN THE \\ EUROPEAN MANUFACTURER \\ OF ELECTRONIC PRODUCTS
}

\author{
Tomasz Urbańczyk
}

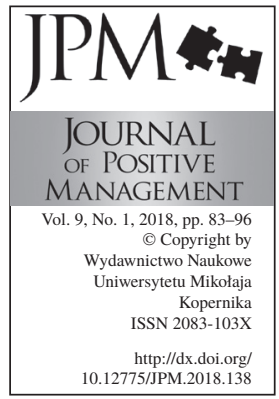

Nicolaus Copernicus University in Torun, Faculty of Economic Sciences

and Management, Torun, Poland

tomasz.urbanczyk@umk.pl

\begin{abstract}
Purpose: The aim of the article it to reveal strategic behaviours of the European manufacturer of electronic products undertaken in the face of world-wide price practices driven by semiconductor business which bring down the competitiveness of European manufacturers of electronic products.
\end{abstract}

Methodology: Case study conducted in the European manufacturer of electronic products based on in-depth interview with purchasing manager having the experience in electronic industry.

Findings: Excellence in strategic supply management is crucial to compete in electronic industry under the strong pressure of Far East competitors. On the one hand tough and coordinated work of procurement, $R \& D$ and quality departments is necessary. It is critical to understand how semiconductor business drives the price policy and set up against the adequate procurement policy. On the other hand being close to the market with the ability of fast customer's requirements fulfilment with flexible and highly automated production gives the real chance to compete with Far East competitors.

Implications: To encourage European manufacturers of electronic products to revise procurement policy and to investigate if semiconductor companies' price practices impair their competitiveness.

Keywords: procurement, purchasing, ethics, semiconductor industry price policy

Paper type: Case study

\section{Introduction}

This article, presented in the form of a case study, aims to reveal unethical price practices in the semiconductor business from the point of view of the author. These practices reduce the competitiveness of many European companies working in the electronics industry.

In the era of very dynamic development of electronic products, applicable to almost every area of our lives - medicine, education, industry, communication, security, household appliances, etc., one can observe a race in the implementation of more and more advanced technical solutions and a price fight leading to price erosion. Indeed, market mechanisms at the level of generally available 
STRATEGIC APPROACH TO PURCHASING

Tomasz Urbańczyk electronic consumer goods function properly. From the point of view of the end customer, all global manufacturers have equal opportunities to compete in the context of technical solutions and prices. After all, the global, free flow of means of production, raw materials and components allows entrepreneurs to optimize their production processes, and thus guarantees them the same opportunities for development and access to markets. As a result, many European factories working in the electronics industry have ceased to exist in the last 20 years. The entrepreneurs moved production to the Far East or went bankrupt. Low production costs were a well-known reason, and precisely lower costs of salaries for employees. In turn, those enterprises that survived and maintained their production in Europe owe it only to functioning in market niches, selling high-margin products or dedicated to strategic sectors of economies (including national defense, energy, technologies of the future).

However, the author of this study puts forward the hypothesis that in the context of the costs of manufacturing in the electronics industry, the payroll costs are not the only factor determining the loss of competitiveness. What's more, for many companies it did not have to be a key factor. The author indicates that in the context of mass production of electronic products referring to the cost structure the largest share is the cost of electronic components, and among them semiconductors. In the "electronic industry, usually 60 to $80 \%$ of the value of the product comes from external suppliers" (Schary and Skjott-Larsen, 2002). The costs of remuneration, technology and development will be on further items. The greater the competition, the higher the share of costs of electronic components in the price of the product and the more important is the fact whether the prices of purchased components are comparable to the prices of components purchased by competitors from the Far East. Based on the case study, the author proves that the pricing policy of distributors and semiconductor manufacturers does not guarantee comparability of component prices, but also affects their over-inflow and thus negatively to the competitiveness of European producers.

\section{The purchasing process and its determinants}

Referring to the hypothesis, the purchasing process is of key importance in the context of the cost structure, which one of the most important and strategic tasks is to determine the prices of purchased components. It seems, therefore, that the high competences of persons responsible for price negotiations must lead to obtaining components at the lowest possible costs. It is also believed that a thorough analysis of the suppliers' market, properly conducted offerings and final negotiations are a guarantee of reaching the lowest prices. Unfortunately, this is not always the case. There may be implicit rules that are not practiced by the free market mechanism. This may be the division of the market into "regional pricing" (Simchi-Levi et al., 2009), where different pricing policies are applied. 
It can be unwritten distribution of clients / tenders between suppliers. It may be a distribution policy which, through direct and exclusive access to customers, imposes high commercial margins. It can also be a sophisticated pricing policy of the manufacturer who is aware of the client's dependence on his technical solution. As a consequence, suppliers will appear to be in competition, but in reality the prices offered will be overstated.

When can you be convinced that prices are actually determined based on the mechanism of the free market? At least in two cases. In the first, when the prices of goods are transparent, and so listed on the stock exchanges, possibly presented in paid services, when they are obtained on the basis of actual market transactions. In the second case, when we can calculate the manufacturing cost of a given good, compare it with its price and recognize the amount of margin on sales or when in cooperation with the supplier the "forward sourcing" process including "creating cost transparency” is already applied (Kerkhoff, 2005). „In fact, the buyer, in order to achieve success, does not operate anything but information" (Kern, 1995).

Therefore, referring to the production of electronic products, you can build the following matrix of uncertainty of the lowest purchase prices (Table 1) with sample data:

\begin{tabular}{lllll}
\hline $\begin{array}{l}\text { Materials / } \\
\text { components used }\end{array}$ & $\begin{array}{l}\text { Percentage share } \\
\text { in the material } \\
\text { cost structure } \\
(\mathbf{B O M})\end{array}$ & $\begin{array}{l}\text { Are } \\
\text { prices } \\
\text { transpa- } \\
\text { rent? }\end{array}$ & $\begin{array}{l}\text { Is the calculation of the } \\
\text { cost of production } \\
\text { and the margin on } \\
\text { sales known? }\end{array}$ & $\begin{array}{l}\text { Percentage } \\
\text { of uncerta- } \\
\text { inty }\end{array}$ \\
\hline Electronic components & 70 & No & No & 70 \\
\hline Plastics & 20 & Yes & No & 0 \\
\hline Wires / cables & 10 & No & Yes & 0 \\
\hline Total: & & & & 70 \\
\hline
\end{tabular}

* BOM - Bill of materials

If, as a result of material cost structure analysis, the uncertainty factor is high and the products manufactured are not competitive or unprofitable, there is a high probability that one of the key reasons may be inflated material purchase prices. Then, using the Pareto or ABC method (Sarjusz-Wolski, 1998), the group of components marked with the uncertainty coefficient should be narrowed down only to those that make up the largest purchasing turnover. Only a list of components prepared in this way, which can still be grouped according to suppliers, producers, assortments should be used for further analysis and price verification.

Awareness of a high uncertainty factor does not solve the problem yet. What's more, there is no ready-made prescription for its solution. The entrepreneur should use his own resources (e.g. by creating an interdisciplinary team) or with the help of other organizations, try to discern the real source of the problem and work out an
Table 1. Matrix of uncertainty of the lowest purchase prices (sample data) Source: Own study. 
STRATEGIC APPROACH TO PURCHASING
Tomasz Urbańczyk

antidote. First of all, it should be verified whether there is any form of dependence on a given supplier (Urbańczyk, 2006). Lysons proposes a comparative method indicating that "there is no aspect of procurement purchases that could not be subject to benchmarking", especially purchase prices (Lysons, 2004). In the case of successfully taken actions, the company should adjust the purchasing policy accordingly.

You can also use the Porter's ,system value”, which "includes the value chains: suppliers, companies, distribution channels and buyers" (Porter, 2001) and then identify in which cells a profit is generated. „In many sectors, profit is concentrated in some links of value and is missing in others" (Slywotzky et al., 2000). Such an analysis, on the one hand, helps in recognizing the allocation of profit for participants in a specific supply chain, in which the enterprise has a problem with generating profit. On the other hand, it allows you to compare yourself with competitors in your sector.

Luzzini and Ronchi (2016) based on the conducted research, showed that "spend rationalization is the only practice significantly improving business performance, at least in the short term". This means that material cost analysis and proper purchasing policy should be a key strategic activity of the company in the context of loss of price competitiveness. "Companies are increasingly considering purchasing and supply activities as a source of competitive advantage" (Spina et al., 2013, via CAPS, 2012).

In the further part of this study, the author presents a similar problem and the method of its solution by a Polish company producing electronic products.

\section{Research methodology}

This study is based on a case study. The analysis was carried out on the basis of an in-depth interview with a purchasing department manager in a Polish company producing electronic measuring devices. The respondent played the role of "key informant". At the same time, the "principle in collection of data in case research" was followed using methods such as "direct observations, content analysis of documents, and archival research" (Voss et al., 2002). It should be mentioned that the surveyed enterprise is a joint-stock company, listed on the Warsaw Stock Exchange and generally available archival reports allow you to easily verify the truthfulness of the theses in the interview in the context of maintaining the production of measuring equipment in the Polish factory after 2008.

\section{Case study: Strategic approach to the purchase process in the semiconductor business}

The Polish manufacturer of electronic measuring devices has started to feel competitive pressure from the Far East since 2008. It turned out that the finished 
same time its price was lower than the material costs of the Polish meter. There were two conclusions. One that the issue of lower labour costs in China was not the only and the main reason for the lower price of the Chinese meter. And the second is that the purchasing policy, although based on strong pillars of competitiveness, was not right.

The first conclusion seemed obvious, but the second one carried some contradiction. Rather, it seemed that the purchasing policy did not guarantee the selection of the most competitive offers and that is why it was inappropriate.

Already in 2002, the Polish company implemented an internet tender application for suppliers of electronic components. It brought surprisingly good results. Suppliers seeing the purchase price and the volume, while being aware that the current price is not a negotiating bluff, they were willing to actively fight for orders. Thanks to the application, price reductions were achieved by several dozen percent. In addition, the benefits in the context of logistic aspects were also attractive because they showed suppliers the potential to buy, set stock levels, defined delivery dates and Incoterms.

It turned out, however, that the concept of tender application, which yielded substantial savings was, after all, a defective tool. While it did very well with regard to components from the commodity group (standardized elements with very comparable parameters produced by many manufacturers), it did not reach the bottom with respect to strategic components, i.e. with a high unit value and with a greater technical diversity between producers.

The main problem concerned inflated prices of strategic components, i.e. silicon based integrated circuits, such as microcontrollers, measurement integrated circuits, memories, and specialized voltage regulators. These integrated circuits are produced in the so-called fabs, which are specialized factories with a very advanced and extremely capital intensive technology (such as for the production of processors in computers).

Integrated circuits are designed in large international corporations, and produced as part of their own factories or using outsourcing (mainly in Taiwan). The silicon wafers manufactured in factories already with electronic integrated circuits (so-called front end) go to much less technologically advanced factories, mainly in the Far East, to cut into individual integrated circuits, connect electrical leads and lock them in a suitable hermetic housing (so-called back end). Only then do they go to direct sales (only for a very narrow group of key customers) and only to selected international distribution networks based on franchise agreements.

Because the Polish company was not eligible for direct sales due to low turnover, it was served by distribution companies.

Seemingly everything looked normal, the manufacturers of integrated circuits competed with each other using the authorized distributors, who also had to compete with each other. 
STRATEGIC APPROACH TO PURCHASING

Tomasz Urbańczyk

As it turned out the Chinese meter contained integrated circuits of the same manufacturers as in the Polish one. Since, therefore, the material cost of the Polish meter was higher than the price of the finished Chinese meter, it meant that the problem of inflated prices of integrated circuits was the source of the problem. Especially that the prices of consumed raw materials such as plastics and copper are transparent, and the remaining cost-generating components were already directly imported from China (including printed circuits boards, displays, transformers).

Both the manufacturers of integrated circuits and distributors claimed that the offered prices are very attractive, even the lowest in the world. In the absence of reaction from suppliers, the following activities were launched in two ways. First of all, work began to calculate the manufacturing cost of integrated circuits. Secondly, since the Chinese producer had to have access to significantly lower prices, attempts were made to reach sources of supply in China.

Thanks to the help of a consulting company from the silicon valley in the US, it was possible to calculate the real costs of producing integrated circuits used in Polish meters. Taking into account the average producer's margin (data available in stock market reports), the expected prices have been set - the so-called target price. The application was clear, the purchase prices were very much inflated. Despite presenting specific arguments to the distributor and producer, this did not affect their positive reaction, as they indicated low credibility of such analyzes.

Only reaching for sources of supply in Asia has brought the expected results. At the same time it could not be done in an official way. No representative of the manufacturer in Asia, or any Asian distributor would agree to sell to Europe due to the risk of losing the franchise agreement. The sale was absolutely forbidden. On the other hand, the purchase of integrated circuits from brokers who are not bound by franchise agreements and operate independently using all available sources of supplies is highly risky due to the lack of guarantees and the possibility of obtaining refurbished integrated circuits - marked as new or even defective. Therefore, getting to the right broker and the ability to verify the originality of integrated circuits was not that easy. Especially that there was a need for systematic deliveries of large volumes and very precisely defined types of integrated circuits at attractive prices.

The prices obtained from the broker, although significantly lower and bringing very large savings, still did not reach the bottom, which was discovered by the analysis of production costs. It was understandable, because the transaction had to be made with a profit by an Asian entrepreneur who, under the pretense of wear in its products, re-sold integrated circuits to the broker. Additionally at least one broker had to earn, and there could have been more in the chain of transactions. Ultimately, however, after a six-month break in purchases from a European distributor, the producer and the distributor resumed negotiations 
and, by reducing their margins, reduced the prices of integrated circuits below brokerage prices.

As the negotiated prices were still higher than calculated, it was time for a revision of the distributor's margin. As the distributor of integrated circuits refused to cooperate on the basis of the proposed agreed transparent margin, a model of such cooperation was proposed to other distributors. Despite their acceptance, the manufacturer refused to sell integrated circuits through them. As it turned out between the producers and distributors, loyalty agreements are concluded, consisting in the protection of the distributor, which will encourage and help to implement a given integrated circuit at the customer's. This is called 'design protection'. The distributor receives a request for quotation from the client or on the basis of a conversation with a customer's development engineer and registers this fact in the manufacturer's system. In this way, it guarantees that for this particular customer and for this particular integrated circuit no other distributor will be able to submit an offer below the standard price from the price list. At this point, it must be pointed out that this price from the price list is dedicated to small quantities and is usually several times higher than the negotiated price for large quantities. In this way, the distributor who obtains project protection is guaranteed a high commercial margin. This is to be a compensation for market activities, promotion of integrated circuits of the producer and technical support for the implementation at the customer's production. In addition, the distributor usually sells the competing producers and it happens that it performs multi-registration, i.e. obtains design protection for the same client project, but technically competing integrated circuits of different manufacturers. Thanks to this, it has a very strong negotiating position towards producers and can secure even a several-ten percent trade margin. In this situation, the manufacturer of integrated circuits, who knows the selling price to the customer and the high margin of the distributor, is not willing to make significant price concessions to the client. It naturally sets up its margin with the distributor's margin and expresses its readiness to lower the price provided that the distributor also lowers its trade margin. However, with design protection, the distributor tries to keep his margin as long as possible, that is, as long as the customer can withstand.

Due to the fact that the manufacturer refused to sell integrated circuits to other distributors at the same price, the Polish meter manufacturer made an ultimatum that if it does not release the design protection, its other components will not be taken into account when designing new products. Especially that the project protection policy in no way was previously declared, and in this particular case the implementation of the integrated circuit for production took place with the participation of another distributor who later lost the franchise agreement. Finally, the manufacturer of integrated circuits released project protection, the distributor was changed, and by agreeing a transparent margin another price reduction was 
STRATEGIC APPROACH TO PURCHASING

Tomasz Urbańczyk achieved for integrated circuits. Whereas the manufacturer of integrated circuits, releasing project protection, consumed part of the previous distributor's margin. It can be said that the margin of the previous distributor has been divided into three parts, between the Polish manufacturer of meters, a new distributor and a manufacturer of integrated circuits. Everyone gained something, but only a few percentage points were missing to achieve the target price.

As a result of the activities carried out, a reduction of the strategic price of the integrated circuit by a total of about $70 \%$ was achieved, which together with the change in the purchasing policy in relation to all integrated circuits allowed for a significant reduction of material costs of the meter and the possibility of price competition with Chinese meters.

It should be noted that in the context of negative experiences of the Polish manufacturer of meters against the producer and distributor who used the practice of high margins, confidence drastically decreased. It was because of the perception of distributive and informational injustice (Liu et al., 2012).

With regard to this manufacturer of integrated circuits, a second choice policy was adopted. That is, the implementation of its components for new products could only be due to the uniqueness of the technical solution, provided that a specific added value or a significantly more advantageous price was obtained. However, the distributor was blacklisted and cooperation with the strategic integrated circuits was completely stopped. In turn, cooperation with other producers and distributors worked very well. The producers, knowing the new purchasing policy, the difficult competitive position of the Polish manufacturer of meters against Chinese competitors, and, above all, the low margin of distributors showed much greater flexibility in price negotiations.

As a result of the experience, the Polish manufacturer of meters radically changed the policy of cooperation with distributors and producers. Engineers from the development office have been cut off from contacts with distributors so that all technical conversations, component selection and price negotiations take place directly with the producers. This allowed for the blocking of practices related to obtaining project protection and high margins by distributors. In addition, the distributors have been selected in such a way that the cooperation is based on an agreed, competitive and transparent commercial margin. The role of the distributor should only be to provide appropriate logistic service. Thanks to this policy, subsequent implementations of the products from the very beginning allowed for the start of production at a low cost. 


\section{Conclusions}

The conclusions of the case analysis can be classified in the following areas:

\subsection{The reasons for the loss of competitiveness of European manufacturers of electronic products}

Many European companies producing electronic products did not withstand strong competition from the Far East. Low labor costs were a common cause. A simple economic calculation clearly showed the cost advantage on the Asian side and the only solution was seen in the transfer or liquidation of production. However, the key problem could have involved inflated material prices. Especially that in the context of electronic components (and especially integrated circuits) there is a lack of transparency, and prices generally available on online sales portals at international distributors are usually several dozen or several hundred percent higher than the lowest producer prices. However, the key influence here is also the diversification of pricing policies of large international corporations manufacturing integrated circuits, who treated the Asian market as a mass market supported with low sales margins and the European market - rich customers with high margins. Perhaps regional pricing brought short-term high profits to these companies, but it certainly contributed to the loss of competitiveness of European producers of electronic products and mass transfer of production from Europe to Asia. As a consequence, corporations and distributors have lost a significant portion of revenues with high margins in Europe for low margins in Asia. This situation can be compared to the "tragedy of the common pasture" (Klimczak, 1997).

\subsection{Relationships in the supply chain}

It must be clearly stated that the strong bargaining position of one of the parties to the business relationship allows it to derive high profits. However, a complete lack of understanding of the business needs of the other weaker party may bring negative effects for it through erosion of profitability, weakening of the market position and even complete cessation of production. As soon as the weaker side made aware of the fact that the other party only faked a partner business relationship, it would seek a riposte with the opportunity. Hence the chances of rebuilding trust and the development of mutual cooperation are negligible. The weaker party will seek to reconfigure the supply chain to improve its competitive position. ,There is now a growing realisation that co-operation between network partners usally leads to improved performance generally. The issue then becomes one of determining how the resutls of that improved performance can be shared amongst the various players. 'Win-win' need not mean 50/50, but at a minimum all partners should benefit and be better off as a result of co-operation" (Christopher, 2016). 
STRATEGIC APPROACH TO PURCHASING

Tomasz Urbańczyk
All participants in the supply chain should be aware that real cooperation is needed for the development of its participants, and not the abuse of its own bargaining power. "Collaboration instead of confrontation in the supply chain is a model of business activity that is successful in such diverse industries as the aviation industry and the sale of food products. There is a series of impressive proofs that tangible benefits can be derived from the integration of the supply chain. It is also possible - in a sense - to say that today "supply chains are competing, not enterprises" (Christopher, 2000).

Cousins et al. (2008) in turn, indicate that in the supply chain between the buyer and the supplier "socialization mechanisms can help build inter-personal relationships and trust within these exchange relationships by facilitating the exchange process, reducing ambiguity and allowing for clearer and more open communication". On the basis of conducted scientific research, it is stated that "socialization mechanisms had a direct effect on business performance".

\subsection{Ethics in business}

Corporations producing integrated circuits along with international distribution through their high-margin policy in Europe and low-margin in Asia, have largely contributed to the reduction of electronic products production in Europe. On the one hand, the lack of knowledge of European buyers about the real costs of manufacturing of integrated circuits was used, and on the other hand, attempts were made to block resale from Asia to Europe and sales prices were encapsulated. One of the methods was to mark commonly known integrated circuits with another symbol so as to prevent resale to Europe and that no real sale price was disclosed in any way. In the face of such a policy of short-term profit maximization, in a sense of collusion of multinational companies and distributors, European producers of electronic products not only felt powerless, but did not even have the awareness of unethical practices. Perhaps there was also lack of inclusion of the European Union bodies to control this phenomenon and attempt to counteract such practices.

It is worth noting that these corporations, as well as international distributors, hold ethical codes. "Research in the United States has shown a slightly negative correlation between having an ethical code and unfair behavior of the company. Probably not because the codes lead to unlawful behavior, but because those companies that are prone to criminal behavior, adopt codes to solve this problem or to improve their image in the eyes of the public" (Donaldson, 1995). In turn Rottenburger et al. (2018) on the basis of conducted survey prove that corporate codes and reminders ,decrease manifestations of deception that are commonly perceived as unethical (lying) but do not interfere with manifestations of deception that do not violate social norms (bluffing)". Bluffing which is defined as "the misrepresentation of one's bargaining position as well as the statement 
of false threats" is not only "unaffected by the increase in moral awareness, but also is considered a negotiation skill and hence is compatible with professional standards". In fact, the division of deception into lie and bluffing, as well as counting bluffing into negotiation skills are relativizing ethics but will never be ethical. The fact that scholars and the business world do not count bluffing as unethical testifies rather how much we got lost in the discernment of the truth and how much our moral systems have been disorted.

Thus in practice, ethical issues and long-term market consequences are reduced to maximizing profit, focusing on arranging business and creating the appearance of a fair market game. "The research of enterprises and the literature of the subject shows that ethics occurs in many mottos and slogans, in missions and visions declared by enterprises, but unfortunately, it is often difficult to find true ethical behavior of enterprises" (Mączyńska, 2007).

\subsection{Recommendations for European manufacturers of electronic products}

Many European companies have irretrievably given their know-how which they have accumulated over the years. And for over a dozen consecutive years, technological progress was enormous, the technical staff trained in Asia and not in Europe. Hence, return is possible but certainly very difficult, especially as there may be a shortage of specialists, knowledge of technological processes and, of course, good practices in the area of purchasing process.

Big companies that still produce in Europe are potentially in the best position. In mass production, material costs usually exceed $60 \%$ of the price of the product, which means that the share of labor is smaller. And in the cost accounting there are other items such as external services, depreciation, energy, maintenance of the factory, IT costs, etc. In addition, wages in Poland, although higher than in China were and are much lower than in Western Europe. On the other hand, in Western Europe there is a significantly higher level of automation of production processes, which to some extent compensates for higher labor costs there. In this context, it is worth using the proposed matrix of uncertainty of the lowest purchase prices (Table 1) and rethink the purchasing policy.

Through an attempt to optimize the purchasing policy, enterprises can significantly reduce material costs and improve their profitability. It must be remembered, however, that facing Asian competition requires, on the one hand, extremely intensive and coordinated work of the purchasing, development and quality departments not only in the area of component cost optimization but also in the context of implementing new technical solutions that add value to customers. So, the strategic supply management is recommended, which is ,the design, development, optimization, and management of the internal end external components of the organization's supply system. Strategic supply management is the final stage in the evolution of purchasing from a cleriacal process to a strategic 
STRATEGIC APPROACH TO PURCHASING

Tomasz Urbańczyk one - a process equal to Marketing, Operations, and Finance in its contribution to the survival and success of the firm" (Burt and Pinkerton, 1996). Hong and Kwon (2012 via Carter and Yan, 2007; Porter and Kramer, 2011; Ryals and Rogers, 2006) show that "traditional back office purchasing function has been evolved to be more cross functional and inter-organisational business processes. Thus, increasingly procurement is becoming a key strategic business process from a transaction-based practice to the most of the business firms". On the other hand, you must constantly strive to automate your production processes and increase production efficiency.

It is also worth bearing in mind that the price is not always the only decision criterion. "Some customers will pay more for convenience or high levels of service and other customers look to buy based on the lowest price they can get" (Hugos, 2011). Sometimes customers are willing to pay a bit more for products manufactured locally from a well-known company, with the conviction that this means proper service, technical support and a real guarantee. In addition, being geographically close to the customer, there is more flexibility in adapting the product to its specific requirements and delivery in a shorter time. However, it should be borne in mind that the higher the price difference, the lower the tendency and the clients open up to a number of risks in order to obtain potentially large savings.

On the other hand, medium and small companies wishing to increase the scale of production and enter new markets will certainly encounter a barrier to high prices of components purchased and sales policies of corporations and distributors. Probably the differentiation of pricing policies of large corporations will gradually disappear in the perspective of the next several years, when wages in China will continue to grow and approach European, and the processes of globalization and information flow will continue to progress.

\section{References}

Burt, D.N., Pinkerton, R.L. (1996), A purchasing manager's guide to strategic proactive procurement, American Management Association, New York.

CAPS (2012), "Snapshot of the CPO Role Shows Significant Change", Inside Supply Management, Vol. 23 No. 8.

Carter, J.R., Yan, T. (2007), “The procurement function's role in strategic outsourcing from a process perspective", International Journal of Procurement Management, Vol. 1, No. 1-2, pp. 210-226.

Christopher, M. (2000), Logistyka i zarzadzanie łańcuchem dostaw, Polskie Centrum Doradztwa Logistycznego, Warszawa.

Christopher, M. (2016), Logistics and supply chain management, Pearson Education Limited, Edinburgh Gate.

Cousins, P.D., Lawson, B., Squire, B. (2008), "Performance measurement in strategic 
buyer-supplier relationships", International Journal of Operations \& Production Management, Vol. 28 No. 3, pp. 238-258. DOI: 10.1108/01443570810856170

Donaldson, T. (1995), „Kiedyś wszedł między wrony, ... no właśnie, co powinieneś robić? Biznes w ujęciu międzynarodowym a relatywizm kulturowy", in: Minus, P.B. (Ed.), Etyka w biznesie, Wydawnictwo Naukowe PWN, Warszawa, pp. 75-76.

Hong, P., Kwon, H. (2012), "Emerging issues of procurement management: A review and prospect", International Journal of Procurement Management, Vol. 5 No. 4, pp. 452-469. DOI: 10.1504/IJPM.2012.047199

Hugos, M.H. (2011), Essentials of Supply Chain Management, John Wiley \& Sons, Inc., Hoboken, New Jersey.

Kerkhoff, G. (2005), The bermuda triangle of business procurement, WILEY-VCH Verlag GmbH\&Co. KGaA, Weinheim.

Kern, F. (1995), Zaopatrzenie jak profesjonalnie kupować, Centrum Kreowania Liderów, Międzyborów.

Klimczak, B. (1997), „Jak uzasadnić potrzebę etyki w działalności gospodarczej?”, in: Dietl, J., Gasparski, W. (Eds.), Etyka biznesu, Wydawnictwo Naukowe PWN, Warszawa, pp. 349-361.

Liu, Y., Huang, Y., Luo, Y., Zhao, Y. (2012), "How does the justice matter in achieving buyer-supplier relationship performance?", Journal of Operations Management, Vol. 30 No. 5, pp. 355-367. DOI: 10.1016/j.jom.2012.03.003

Luzzini, D., Ronchi, S. (2016), “Cinderella purchasing transformation: linking purchasing status to purchasing practices and business performance", Production Planning \& Control, Vol. 27 No. 10, pp. 787-796. DOI: 10.1080/09537287.2015.1137986

Lysons, K. (2004), Zakupy zaopatrzeniowe, Polskie Wydawnictwo Ekonomiczne, Warszawa.

Mączyńska, E. (2007), „Upadłości przedsiębiorstw a etyka”, in: Klimczak, B., LewickaStrzałecka, A. (Ed.), Etyka i ekonomia, Wydawnictwo Polskiego Towarzystwa Ekonomicznego, Warszawa, pp. 181-182.

Porter, M.E. (2001), Porter o konkurencji, Polskie Wydawnictwo Ekonomiczne, Warszawa.

Porter, M.E., Kramer, M.R. (2011) "The big idea: creating shared value", Harvard Business Review, January/February, Vol. 89 No. 1, pp. 63-77.

Rottenburger, J.R., Carter, C.R., Kaufmann, L. (2018), “It's alright, it's just a bluff: Why do corporate codes reduce lying, but not bluffing?", Journal of Purchasing and Supply Management. DOI: 10.1016/j.pursup.2018.02.004.

Ryals, L., Rogers, B. (2006) "Holding up the mirror: the impact of strategic procurement practices on account management", Business Horizons, Vol. 49 No. 1, pp. 41-50.

Sarjusz-Wolski, Z. (1998), Strategia zarzadzania zaopatrzeniem, Agencja Wydawnicza Placet, Warszawa.

Schary, P.B., Skjott-Larsen, T. (2002), Zarządzanie globalnym łańcuchem podaży, Wydawnictwo Naukowe PWN, Warszawa.

Simchi-Levi, D., Kaminsky, P., Simchi-Levi, E. (2009), Designing and managing the supply chain: concepts, stategies and case studies, McGraw-Hill Education, New York.

Slywotzky, A.J., Morrison, D.J., Andelman, B. (2000), Strefa zysku, Polskie Wydawnictwo Ekonomiczne, Warszawa. 
STRATEGIC

APPROACH TO

PURCHASING

Tomasz Urbańczyk
Spina, G., Caniato, F., Luzzini, D., Ronchi, S. (2013), "Past, present and future trends of purchasing and supply management: An extensive literature review", Industrial Marketing Management, Vol. 42 No. 8, pp. 1202-1212. DOI: 10.1016/j.indmarman.2013.04.001

Urbańczyk, T. (2006), „Tworzenie sieci dostaw”, in: Ciesielski, M. (Ed.), Logistyka w biznesie, Polskie Wydawnictwo Ekonomiczne, Warszawa.

Voss, C., Tsikriktsis, N., Frohlich, M. (2002), „Case research in operations management”, International Journal of Operations \& Production Management, Vol. 22 No. 2, pp. 195-219. 